\title{
Seasonal and habitat structure of an anuran assemblage in a semideciduous forest area in Southeast Brazil
}

\author{
ELVIS A. PEREIRA, MATHEUS O. NEVES, JOSÉ LUIZ M.M. SUGAI, RENATO N. FEIO \& \\ DIEGO J. SANTANA
}

\begin{abstract}
In this study, we evaluated the reproductive activity and the temporal and spatial distributions of anuran assemblages in three environments within a semideciduous forest in Southeast Brazil, located at Municipality of Barão de Monte Alto, State of Minas Gerais, Brazil. The field activities were carried out during three consecutive days, monthly throughout the rainy seasons of 2013-2014 and 2014-2015. We recorded 28 anurans species, distributed in eight families. We observed the spatial-temporal distribution of some species, and their associated reproductive behaviors through exploration of vocalizations at different sites. The spatial and temporal distribution of the species seems to adapt to abiotic and biotic factors of their environment.
\end{abstract}

Key words: Anuran community, community ecology, environmental heterogeneity, niche breadth, vocalization sites.

\section{INTRODUCTION}

Information about anuran habitat use and reproductive ecology allows us to interpret the relationships between these animals and abiotic and biotic factors (Eterovick \& Sazima 2004). In several vertebrate groups (e.g. birds, anurans, mammals), it has been shown that the coexistence of populations in the same area is facilitated by ecological differences (e.g. habitats, microhabitats, seasonality), due in part to interspecific behavioral interactions, involving the social organization and spatial and temporal distribution of the species in the communities (Cardoso et al. 1989, Cardoso \& Haddad 1992, Menin et al. 2005, Vogel et al. 2011, van Beest et al. 2014, Costa et al. 2016, Cloyed \& Eason 2017, Schirmer et al. 2019). Currently, the most functional concept of an ecological community is defined as a group of organisms that coexist in a determined habitat and also interact with one another and the surrounding environment (Begon et al. 1990). The structure of adult amphibian assemblages has been studied based on habitat and microhabitat (Eterovick \& Sazima 2000, Rojas-Ahumada et al. 2012), and in terms of reproductive periods (Aichinger 1987, Sabbag \& Zina 2011). Intuitively, due to morphological variability associated with certain clades of amphibians (e.g. arboreal, aquatic), we assume that phylogenetic relationships have a significant effect on the structure of amphibian communities.

Amphibians exhibit different strategies for occupying their environment. The occupation by species differs mainly related to vegetation structure (for species in the forest and open areas), as well as the duration of water bodies 
(temporary or permanent) (Díaz-Paniagua 1990, Rossa-Feres \& Jim 2001, Bertoluci \& Rodrigues 2002). However, several characteristics of the habitat such as food availability, hydroperiod, availability of oviposition sites, rainfall, and refuges determine the patterns of organization of anuran assemblages (Lillywhite et al. 1973, Crump 1974, Toft 1985, Pulliam 1989, Barbault 1991, Arzabe 1999, Skelly et al. 1999, Eterovick \& Sazima 2000, Eterovick \& Fernandes 2001, Prado et al. 2005, Richter-Boix et al. 2006).

The relationship between environmental heterogeneity and species diversity can be explained by habitat heterogeneity (Simpson 1949, MacArthur \& MacArthur 1961, MacArthur \& Wilson 1967). Studies about amphibians have demonstrated that complex and heterogeneous environments promote more microhabitats and ways of exploiting environmental resources, and thus, allow for a larger group of species to co-occur (Pianka 1969, Duellman \& Trueb 1986, Cardoso et al. 1989, Pombal Junior. 1997, Brandão \& Araújo 1998, Bernarde \& Kokubum 1999, Conte \& Machado 2005, Vasconcelos \& Rossa-Feres 2005). In anurans communities, species coexistence may result in a differential use of habitats for vocalization, reproduction and larval developmental activities (Duellman \& Trueb 1986, Bernarde \& Anjos 1999, Bastos 2007, Purrenhage \& Boone 2009). Other influential factores include the presence of bromeliads (Schineider \& Teixeira 2001, Bastazini et al. 2007), soil and moisture (Bernarde \& Anjos 1999, Toledo et al. 2003, Bastazini et al. 2007), leaf litter, fallen logs, and temporary pools (Bernardo \& Anjos 1999, Toledo et al. 2003, Bastazini et al. 2007). Some species show plasticity in the use of spatial resources (Santos et al. 2008) and variation in the availability of these resources can affect the number of species, reproductive modes, and the activity period of anurans (Duellman \& Trueb 1986, Kopp et al. 2010).
Another intrinsic trait structuring an anuran community should consider phylogeny as an explanatory variable, which may reveal how related assemblages occupy different environments, and also understand why certain assemblages are similar or different (Losos 1996). Studies about the structure of assemblages are still mainly descriptive (Wells 2007) and those that consider the effect of phylogeny are scarce, especially for amphibians (Eterovick \& Fernandes 2001, Eterovick et al. 2010).

Most of the studies focusing on Neotropical anuran assemblages were carried out in the Amazon basin (e.g. Crump 1974, Aichinger 1987, Neckel-Oliveira et al. 2000) and in the Atlantic Forest, Southeastern Brazil (e.g. Haddad \& Sazima, 1992, Bertoluci 1998, Bertoluci \& Rodrigues 2002). Their findings show that most species reproduce during the rainy season, and a strong association between abundance and species richness with rainfall and temperature (Eterovick \& Sazima 2000, Toledo et al. 2003, Santos et al. 2008, Kopp et al. 2010, Hartel et al. 2011, Maffei et al. 2011). According to Santos et al. (2009), the species composition of anurans in semideciduous forest areas is more similar to those recorded in areas of Cerrado, Pantanal and even Pampa than with the communities of the ombrophilic areas of the Atlantic Forest. It is expected that studies of anuran communities in semideciduous forest will demonstrate several levels of reproductive segregation among species in the same community. The species may range from complete spatial and/or temporal sharing, to total overlapping of these factors (e.g. Bernarde \& Kokubum 1999, Rossa-Feres \& Jim 2001).

The general objective of this study was to describe the spatial-temporal distributions of anurans in a semideciduous forest area, located in the Municipality of Barão de Monte Alto, State of Minas Gerais, Brazil. More specifically, 
we first described the reproductive period and activity of the species during two rainy seasons, as well as their spatial distribution considering reproductive site characteristics. We also tested the hypothesis that phylogenetic distances, reproductive mode, and reproductive period explain differences in reproductive site characteristics of anurans.

\section{MATERIALS AND METHODS}

\section{Study area}

The study was carried out in the Municipality

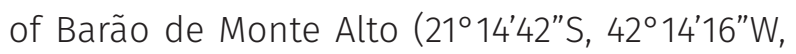

WGS84), State of Minas Gerais. The climate of the region is classified as Aw (sensu Köppen 1918), with a dry season that coincides with winter, and the maximum observed precipitation for the driest month of this season is less than 60 mm (Kottek et al. 2006). The local vegetation is characterized as Seasonal semi-deciduous Forest of lowlands between 132 and $700 \mathrm{~m}$ elevation (Veloso et al. 1991). Mean annual rainfall is about $1.287 \mathrm{~mm}$ and the mean annual temperature is $22.6^{\circ} \mathrm{C}$. We monitored three habitats: a temporary stream and marsh (Area A) in a forested area, a temporary marsh and pond (Area B), and a marsh and permanent pond (Area C) (Figure 1; Table I).

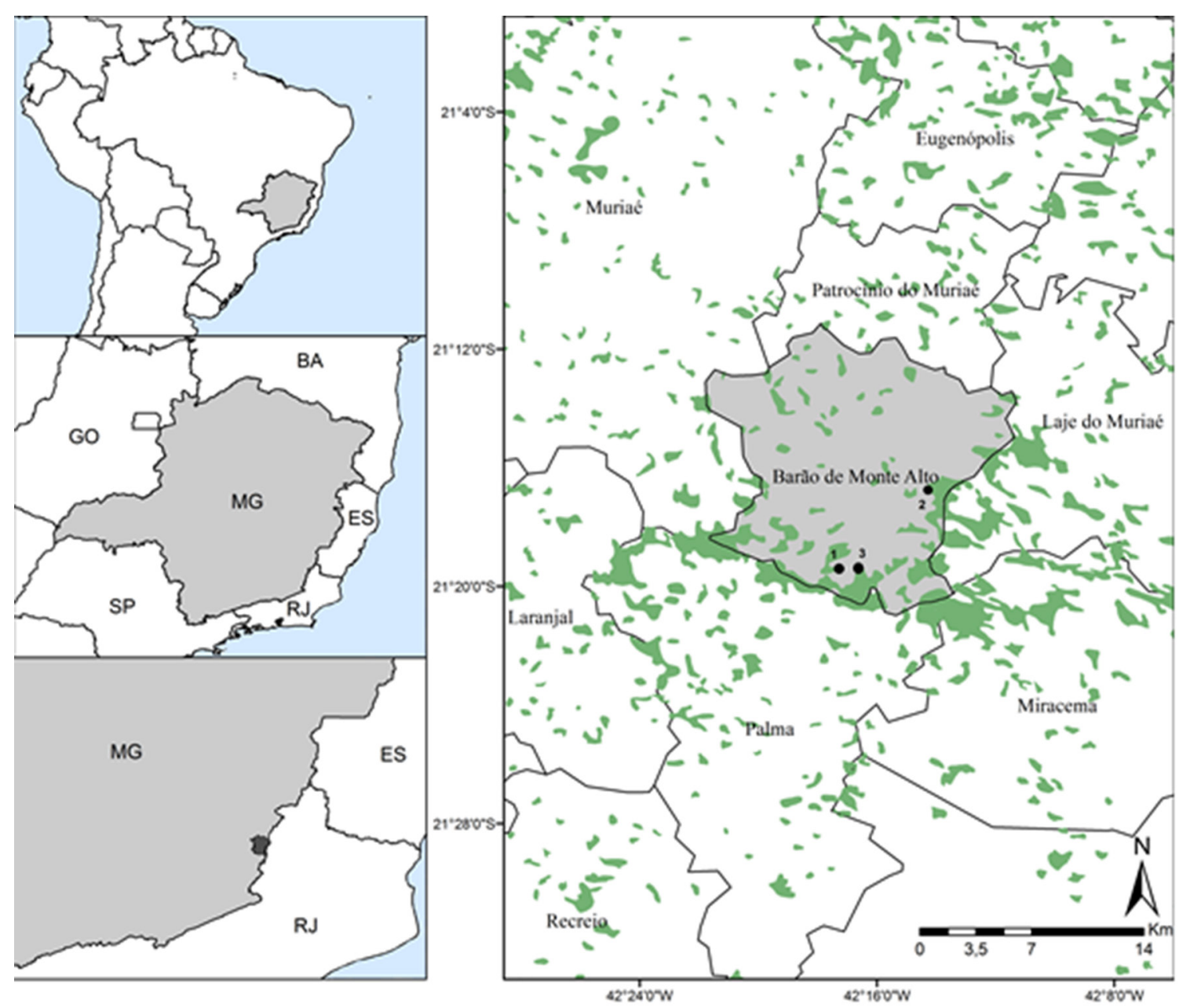

Figure 1. Location of the Municipality of Barão de Monte Alto, State of Minas Gerais, Brazil. Points: (1) Area A, (2) Area B and (3) Area C. 
Table I. Environments monitored during rainy seasons 2013-2014 and 2014-2015 (October to March, respectively) in the Municipality of Barão de Monte Alto, State of Minas Gerais, Brazil.

\begin{tabular}{|c|c|c|c|c|}
\hline \multicolumn{2}{|c|}{ Environment } & Coordinates & $\begin{array}{c}\text { Elevation } \\
(\mathrm{m})\end{array}$ & Description \\
\hline 1 & Area A & $\begin{array}{c}21^{\circ} 32^{\prime} 39^{\prime \prime} \mathrm{S} \\
42^{\circ} 27^{\prime} 55^{\prime \prime} \mathrm{W}\end{array}$ & $390 \mathrm{~m}$ & $\begin{array}{c}50 \mathrm{~m} \text { permanent marsh in a secondary forest area surrounded } \\
\text { by trees and bushes on the banks and permanent } \\
\text { anthropogenic pond with approximately } 1.100 \mathrm{~m}^{2} \text { of water } \\
\text { surface, with secondary forest fragment and pasture on the } \\
\text { banks. }\end{array}$ \\
\hline 2 & Area B & $\begin{array}{l}21^{\circ} 27^{\prime} 59^{\prime \prime} \mathrm{S} \\
42^{\circ} 23^{\prime} 50^{\prime \prime} \mathrm{W}\end{array}$ & $560 \mathrm{~m}$ & $\begin{array}{c}200 \mathrm{~m} \text { a temporary stream within semideciduous forest with } \\
\text { sandy/rocky bed and riparian forest preserved. }\end{array}$ \\
\hline 3 & Area C & $\begin{array}{l}21^{\circ} 32^{\prime} 42^{\prime \prime} \mathrm{S} \\
42^{\circ} 29^{\prime} 00^{\prime \prime} \mathrm{W}\end{array}$ & $360 \mathrm{~m}$ & $\begin{array}{c}150 \mathrm{~m}^{2} \text { temporary marsh surrounded by pastures and 4.000m } \\
\text { permanent pond stretch with secondary forest fragment and } \\
\text { pasture on the banks. }\end{array}$ \\
\hline
\end{tabular}

\section{Fieldwork}

Field studies about temporal and spatial distributions of anurans were carried out during three consecutive days, monthly throughout the rainy seasons of 2013-2014 and 2014-2015 (October to March), monitoring one area per night. We performed the fieldwork between 18:00 $\mathrm{h}$ and 23:30 h, with a total of 88 observation hours, and a sampling effort of 196h/person. The same person counted and carried out the measurements with the individuals. Monthly climatic data of mean temperature and accumulated rainfall were obtained from the Automatic Weather Station of Muriaé, located approximately $19 \mathrm{~km}$ in a straight line from the study area. At the beginning of each collection, we also measured air and water temperature of each environment with a Digital Thermometer Western with Clock for Internal and External Environments (Internal Temperature: $-10^{\circ} \mathrm{C}$ to $+50^{\circ} \mathrm{C}$, External Temperature: $-50^{\circ} \mathrm{C}$ to $+70^{\circ} \mathrm{C}$, Accuracy: $\pm 1^{\circ} \mathrm{C}$, Clock Accuracy: \pm 1 minute/ month).

We performed active searches for anurans in the field, registering species found, along with data on microhabitat that they used as calling sites. We established seven possible calling site microhabitats: exposed roots, rock, leaf litter, cattail leaf, ground, partially submerged, and grass, for use in the descriptive part and to acquire the spatial measurements of the species. From the data obtained from these seven microhabitats, we defined four other types of microhabitats (height above water and distance from water, microhabitat (separated into fifteen new categories): ground, rock; ground and rock; ground, rock and root; ground and partially submerged; root; leaf litter; ground and grass; partially submerged; leaf litter and grass; leaf litter and cattail; partially submerged and grass; grass; grass and cattail; cattail; and extract (separated into 2 categories): herbaceous or arboreal) to test the hypotheses. For species that were actively calling during the same night and in the same habitat, we estimated the number of calling males and assigned them to the following abundance classes: (1) 1-2; (2) 3-10; (3) 11-50 and (4) more than 50 calling individuals. We recorded the calls with the Sony IC Recorder to help with species identification and deposited the sound files in the Fonoteca Mapinguari da Universidade Federal de Mato Grosso do Sul. An estimated number of calling individuals is widely used for anurans (Heyer et al. 1994) and assessed as efficient, provided that 
estimates are always done by the same observer (Shirose et al. 1997).

Based on calling activity periods during the months of monitoring, we defined five different reproductive patterns (adapted from Canelas \& Bertoluci 2007): (1) species that call in the beginning of the rainy season; (2) species that call in the middle of the rainy season; (3) species that call at the end of the rainy season; (4) species that call throughout the entire rainy season; (5) species that call only in the beginning and end of the rainy season. The vertical and horizontal distribution of species was studied by characterizing the calling sites, and measuring the height and distance (through a tape measure) that animals were located in the microenvironment in relation to the nearest body of water. We also noted age and reproductive data, such as young individuals, ovigerous females, froglets, couples in amplexus, and tadpoles.

All voucher specimens were collected with a license from the Instituto Chico Mendes de Conservação da Biodiversidade (ICMBio $n^{\circ}$ 40744-1 e 40744-2), and were housed in the herpetological collection of the Museu de Zoologia João Moojen, Universidade Federal de Viçosa (MZUFV).

\section{Statistical analysis}

We used four characteristics to describe the reproductive sites of species: height and distance from water; microhabitat, and extract. We organized each individual based on reproductive site characteristics using Nonmetric Multidimensional Scaling (NMDS) (Manly 1994), combining the two rainy periods (October to March, 2013-14 and 2014-15). Thus, we defined the response variable as the axis of the NMDS in one dimension, which recovered $92 \%$ of the variance of the original distances $\left(r^{2}=0.929\right)$. We used the phylogenetic tree based on Pyron \&
Wiens (2011) and reduced the tree to only one species per genus that was included in our sampling, using the function drop.tip () and created a matrix of phylogenetic distances among each genus. From this distance, we ordered genera based on phylogenetic relatedness reproductive modes following Haddad et al. (2013) and reproductive period determined during this study. Due to correlations among some of these explanatory variables, we applied a Variation Partitioning method (Borcard et al. 1992) using partial regression, which results in percentages of variation explained only by each explanatory variable and shared by them. The variation partitioning results were represented in a Venn diagram. We also verified the relationship between rainfall and number of species in calling sites using a linear regression with a Poisson distribution.

The significance level used to explain the spatial organization of the composition of species in the habitats was $P<0.05$. For this, the data were analyzed using the statistical software $R$ version 3.1.3. ( $R$ Core Team 2015), using the "cluster" package (Maechler et al. 2015) to create the Gower distance matrix among the species based on the environmental measurements: we used the "ape" package (Paradis et al. 2004) to create the phylogenetic distance matrices among genera, and finally the "vegan" package (Oksanen et al. 2015) to create the NMDS and variation partitioning.

\section{RESULTS}

In the three monitored habitats in the study area, we found 28 species of anurans belonging to the families Bufonidae (1), Brachycephalidae (1), Craugastoridae (1), Cycloramphydae (1), Hylidae (15), Microhylidae (1), Leptodactylidae (6), Odontophrynidae (1), and Ranidae (1). Area 
B showed the greatest richness with 21 species present, of these, 11 are hylids. Areas A and C, however, showed a richness of 20 species each, but in Area A there were 14 hylids and in Area C only 11 (Table II). Table III (a, b and c) shows the results of the spatial-temporal distribution of species found over the six months of sampling of the rainy season (2013-14 and 2014-15).

In the months of February and March, we found the fewest number of species (14) with calling activity, and in December we registered the highest number of calling species (20). Only three species did not fit into the established reproductive patterns due to absence of calling observations (Adenomera marmorata), or because it had incipient vocalization activity (Elachistocleis cesarii and Scinax fuscovarius).

With environmental occupation, we found six species (22\%) using just one single type of microhabitat as a calling site, whereas 10 (37\%) species used two and/or three microhabitats, and only one species (3.7\%) used four microhabitats (Pithecopus rohdei). The grass microhabitat was utilized most (21 species: 77\%), whereas rock microhabitat was utilized least (one species: Thoropa miliaris). Of the seven microhabitats defined in this study, Area A was the only one that contained all of the different types of calling sites (Table IIla).

Of the registered species, five (17.8\%) occurred exclusively in Area A: Dendropsophus pseudomeridianus, Elachistocleis cesarii, Adenomera marmorata, Proceratophrys boiei, and Leptodactylus catesbeianus. On the other hand, Area B had only three (10.7\%) exclusive species: Ischnocnema sp., Leptodactylus labyrinthicus, and Leptodactylus spixi. Only Ischnocnema sp. occurred exclusively in Area C (Table II).

In both rainy seasons sampled, the reproductive activity of the species, characterized by the presence of calling males, was not associated with the highest rainfall, $(Z=0.775$, $P=0.438$ ) (Figure 2). Considering the overall analysis (sum of the periods 2013-14 and 201415) the peaks of abundance of calling males, with more than 50 individuals vocalizing, were recorded at the beginning (October 2013) and end (March 2015) of the rainy season (Tables IIla, $b$ and $c)$.

Through regressions of all these explanatory variables with species scores, only reproductive modes $(0.02 \%)$, genus $(0.06 \%)$, and reproductive period $(0.16 \%)$ were significant. However, there was no significant interaction among these three variables, but reproductive mode and genus shared $0.08 \%$ of the variables (Figure 3 ). We also removed from the phylogenetic tree of Pyron (Pyron \& Wiens 2011) only the families and genera included in the sample design, we defined the scores and based on this tree, we made a patristic distance matrix between each family and gender. From this distance we order families and genera based on phylogenetic proximity. The influence of historical factors was significant, the phylogeny explained part of the variation in the use of micro-habitat by the species, being basically related to the basal separation between Hylidae and other terrestrial families. 
Table II. List of anurans species and habitats where they occur in the Municipality of Barão de Monte Alto, State of Minas Gerais, Brazil: Area A, Area B and Area C. RM - Reproductive Modes (According to Haddad \& Prado 2005). (-) No species.

\begin{tabular}{|c|c|c|c|c|}
\hline \multirow{2}{*}{ Taxa } & \multicolumn{3}{|c|}{ Environments } & \multirow{2}{*}{ RM } \\
\hline & Area A & Area B & Area C & \\
\hline \multicolumn{5}{|l|}{ Bufonidae } \\
\hline Rhinella ornata (Spix 1824) & $x$ & $x$ & $x$ & 1 \\
\hline \multicolumn{5}{|l|}{ Brachycephalidae } \\
\hline Ischnocnema sp. & - & - & $x$ & 23 \\
\hline \multicolumn{5}{|l|}{ Craugastoridae } \\
\hline Haddadus binotatus (Spix 1824) & $x$ & $x$ & $x$ & 23 \\
\hline \multicolumn{5}{|l|}{ Cycloramphidae } \\
\hline Thoropa miliaris (Spix 1824) & $x$ & $x$ & $x$ & 19 \\
\hline \multicolumn{5}{|l|}{ Hylidae } \\
\hline Dendropsophus bipunctatus (Spix 1824) & $x$ & - & - & 1 \\
\hline Dendropsophus branneri (Cochran 1948) & $x$ & $x$ & $x$ & 1 \\
\hline Dendropsophus decipiens (Lutz 1925) & $x$ & - & $x$ & 24 \\
\hline Dendropsophus elegans (Wied-Neuwied 1824) & $x$ & $x$ & $x$ & 1 \\
\hline Dendropsophus minutus (Peters 1872) & $x$ & $x$ & $x$ & 1 \\
\hline Dendropsophus pseudomeridianus (Cruz, Caramaschi \& Dias 2000) & - & $x$ & - & 1 \\
\hline Boana albomarginata (Spix 1824) & $x$ & - & $x$ & 1 \\
\hline Boana albopunctata (Spix 1824) & $x$ & $x$ & $x$ & 1 \\
\hline Boana faber (Wied-Neuwied 1821) & $x$ & $x$ & $x$ & 4 \\
\hline Boana pardalis (Spix 1824) & $x$ & $x$ & $x$ & 4 \\
\hline Boana polytaenia (Cope 1870 “1869”) & $x$ & $x$ & $x$ & 1 \\
\hline Boana semilineata (Spix 1824) & $x$ & $x$ & $x$ & 1 \\
\hline Scinax crospedospilus (Lutz 1925) & $x$ & - & $x$ & 1 \\
\hline Scinax fuscovarius (Lutz 1925) & $x$ & $x$ & - & 1 \\
\hline \multicolumn{5}{|l|}{ Microhylidae } \\
\hline Elachistocleis cesarii (Schneider 1799) & - & $x$ & - & 1 \\
\hline \multicolumn{5}{|l|}{ Leptodactylidae } \\
\hline Adenomera marmorata Steindachner 1867 & - & $x$ & - & 32 \\
\hline Leptodactylus fuscus (Schneider 1799) & $x$ & - & $x$ & 30 \\
\hline Leptodactylus labyrinthicus (Spix 1824) & - & - & $x$ & 11 \\
\hline Leptodactylus latrans (Steffen 1815) & $x$ & $x$ & $x$ & 11 \\
\hline Leptodactylus spixi Heyer 1983 & - & $x$ & $x$ & 30 \\
\hline Physalaemus cuvieri Fitzinger 1826 & $x$ & $x$ & $x$ & 11 \\
\hline \multicolumn{5}{|l|}{ Odontophrynidae } \\
\hline Proceratophrys boiei (Wied-Neuwied 1825) & - & $x$ & - & 2 \\
\hline
\end{tabular}


Table II. Continuation

\begin{tabular}{|c|c|c|c|c|}
\hline \multirow{2}{*}{ Taxa } & \multicolumn{3}{|c|}{ Environments } & \multirow{2}{*}{ RM } \\
\hline & Area A & Area B & Area C & \\
\hline \multicolumn{5}{|l|}{ Phyllomedusidae } \\
\hline Pithecopus rohdei (Mertens 1926) & $x$ & $x$ & - & 24 \\
\hline \multicolumn{5}{|l|}{ Ranidae } \\
\hline Lithobates catesbeianus (Shaw 1802) & - & $x$ & - & - \\
\hline Total & 20 & 21 & 20 & \\
\hline
\end{tabular}

Table III. Areas in the Municipality of Barão de Monte Alto, State of Minas Gerais, Brazil. Male classes in vocalization activity: - 1-2; - 3-10; - 11-50 and - $\square$ over 50. S: Found only individuals that were not vocalizing; Ov: ovate; Ju: juvenile; Fg: froglet. AE (Arboreal Extract): H: herbaceous; Sh: shrubby. MV (Microenvionment Vocalization): Lt: litter; Gn: ground; Gr: grass; C: cattail; Ro: rock; Rt: root, PS: partially submerged. Months of the rainy season (2013-14 and 2014-15).

\begin{tabular}{|c|c|c|c|c|c|c|c|c|}
\hline (a) Species & Oct & Nov & Dec & Jan & Feb & Mar & $\mathrm{AE}$ & MV \\
\hline D. bipunctatus & & & & & & & Sh, H & $\mathrm{C}, \mathrm{Gr}$ \\
\hline D. branneri & & & Ju & & & & $\mathrm{H}$ & Gr, C \\
\hline D. decipiens & S & & & & & & $\mathrm{H}$ & Gr, C \\
\hline D. elegans & & & Ju & & S, Ju & & $\mathrm{H}$ & $\mathrm{C}, \mathrm{Gr}$ \\
\hline D. minutus & & & & & & & $\mathrm{H}$ & Gr, C \\
\hline B. albomarginata & & & & & & & $\mathrm{Sh}, \mathrm{H}$ & Gr, C \\
\hline B. albopunctata & & & & & $\mathrm{S}$ & & $\mathrm{H}$ & Gr, C \\
\hline H. binotatus & & & & & & & $\mathrm{H}$ & Gn \\
\hline B. faber & & & & Ju & & & $\mathrm{H}$ & Gr, PS \\
\hline B. pardalis & & & & & & & $\mathrm{H}$ & $\mathrm{C}, \mathrm{Gr}$ \\
\hline B. polytaenia & & & & & & & $\mathrm{H}$ & Gr, C \\
\hline B. semilineata & & & $\mathrm{S}, \mathrm{Ju}$ & Ju & & $\mathrm{Fg}, J u$ & $\mathrm{H}$ & $\mathrm{C}, \mathrm{Gr}$ \\
\hline L. fuscus & & & & & & & $\mathrm{H}$ & Gn \\
\hline L. latrans & $\mathrm{S}, \mathrm{Ju}$ & $\mathrm{S}, \mathrm{Ju}$ & $\mathrm{S}$ & $\mathrm{S}, \mathrm{Ju}$ & S & $\mathrm{S}, \mathrm{Ju}$ & $\mathrm{H}$ & $\mathrm{Gn}, \mathrm{Gr}$ \\
\hline P. curvieri & & & & & & & $\mathrm{H}$ & PS \\
\hline P. rohdei & & Ju & & & & & $\mathrm{H}$ & $\mathrm{Gn}, \mathrm{Gr}$ \\
\hline (a) Species & Oct & Nov & Dec & Jan & Feb & Mar & $\mathrm{AE}$ & MV \\
\hline R. ornata & & & & & & & $\mathrm{H}$ & Gn \\
\hline S. crospedospilus & & & & & & & Sh, H & Gr \\
\hline S. fuscovarius & & & & & & & $\mathrm{H}$ & $\mathrm{Gr}$ \\
\hline T. miliaris & & & & $\mathrm{S}$ & & & $\mathrm{H}$ & Gn \\
\hline $\mathbf{N}^{\circ}$ species vocalizing & 11 & 12 & 10 & 10 & 07 & 10 & & \\
\hline$N^{\circ}$ species registered & 13 & 13 & 11 & 11 & 09 & 11 & & \\
\hline
\end{tabular}


Table III. Continuation

\begin{tabular}{|c|c|c|c|c|c|c|c|c|}
\hline (b) Species & Oct & Nov & Dec & Jan & Feb & Mar & AE & MV \\
\hline A. marmorata & & & & S & & & $\mathrm{H}$ & $\mathrm{Lt}$ \\
\hline D. branneri & & & & & & & $\mathrm{H}$ & $\mathrm{C}, \mathrm{Gr}$ \\
\hline D. elegans & & & & & & & $\mathrm{H}$ & C, Gr \\
\hline D. minutus & & & & & & & $\mathrm{H}$ & C, Gr \\
\hline D. pseudomeridianus & & & & & & & $\mathrm{H}$ & $\mathrm{Gr}$ \\
\hline E. cesarii & & & & & & & $\mathrm{H}$ & Gn \\
\hline B. albopunctata & & & Ju & & & & $\mathrm{H}$ & C, Gr \\
\hline H. binotatus & & & & S & & & $\mathrm{H}$ & Gn \\
\hline B. faber & & & S & & & & Sh, H & $\mathrm{PS}, \mathrm{Gr}$ \\
\hline B. pardalis & & & & ju & & & $\mathrm{H}$ & C, Gn, Gr \\
\hline B. polytaenia & & & S, Ju & & & & $\mathrm{H}$ & $\mathrm{C}, \mathrm{Gr}$ \\
\hline B. semilineata & $\mathrm{Fg}$ & $\mathrm{S}, \mathrm{Fg}$ & & & $\mathrm{Fg}$ & $\mathrm{Fg}$ & $\mathrm{H}$ & $\mathrm{C}, \mathrm{Gn}, \mathrm{Gr}$ \\
\hline L. latrans & s & & s & Ju & s & & $\mathrm{H}$ & Gn, Gr, PS \\
\hline P. boiei & S & S & & $\mathrm{S}, \mathrm{Ju}, \mathrm{Fg}$ & & S & $\mathrm{H}$ & Rt, Gn, Lt \\
\hline P. cuvieri & & & $\mathrm{J}, \mathrm{Fg}$ & & & & $\mathrm{H}$ & PS \\
\hline P. rohdei & . & & S & & & & $\mathrm{H}$ & $\mathrm{Lt}, \mathrm{C}, \mathrm{Gn}, \mathrm{Gr}$ \\
\hline R. ornata & S & & & & $\mathrm{S}$ & & $\mathrm{H}$ & $\mathrm{Gn}, \mathrm{Gr}$ \\
\hline S. fuscovarius & S & S & & & S & & Sh, H & C, Gn, Gr \\
\hline T. miliaris & S & S & . & $S$ & & S & $\mathrm{H}$ & Rt, Ro, Gn \\
\hline $\mathbf{N}^{\circ}$ species vocalizing & 10 & 11 & 12 & 10 & 10 & 10 & & \\
\hline $\mathbf{N}^{\circ}$ species registered & 12 & 12 & 15 & 12 & 13 & 10 & & \\
\hline (c) Species & Oct & Nov & Dec & Jan & Feb & Mar & $\mathrm{AE}$ & MV \\
\hline D. branneri & & & & Ju & & & $\mathrm{H}$ & $\mathrm{C}, \mathrm{Gr}$ \\
\hline D. decipiens & Ov & & & & & & $\mathrm{H}$ & $\mathrm{Gr}$ \\
\hline D. elegans & Ov & Ju, Ov & Ju, Ov & & $\mathrm{Fg}$ & $\mathrm{u}, \mathrm{O} \mathrm{Fg}$ & $\mathrm{H}$ & $\mathrm{C}, \mathrm{Gr}$ \\
\hline D. minutus & & & & Ov & Ju, Ov, Fg & & $\mathrm{H}$ & $\mathrm{C}, \mathrm{Gr}$ \\
\hline (c) Species & Oct & Nov & Dec & Jan & Feb & Mar & $\mathrm{AE}$ & MV \\
\hline B. albomarginata & & & & & & & $\mathrm{Sh}, \mathrm{H}$ & $\mathrm{Gr}, \mathrm{C}$ \\
\hline B. albopunctata & & & & & & & $\mathrm{H}$ & $\mathrm{Gr}, \mathrm{C}$ \\
\hline H. binotatus & S & & S & S & & & $\mathrm{H}$ & Gn \\
\hline B. faber & & & & & & & $\mathrm{H}$ & PS, Gr, Gn \\
\hline B. pardalis & & $\mathrm{Fg}$ & & & & & $\mathrm{H}$ & $\mathrm{Gr}$ \\
\hline B. polytaenia & & & & & & & $\mathrm{H}$ & C \\
\hline B. semilineata & $\mathrm{Ju}, \mathrm{Fg}$ & & $\mathrm{Fg}$ & $\mathrm{Ju}, \mathrm{Fg}$ & & & $\mathrm{H}$ & $\mathrm{Gr}$ \\
\hline
\end{tabular}


Table III. Continuation

\begin{tabular}{|c|c|c|c|c|c|c|c|c|}
\hline Ischnocnema sp. & & & & & & & Sh & $\mathrm{Gr}$ \\
\hline L. fuscus & & & Ju & S & & & $\mathrm{H}$ & $\mathrm{Gn}, \mathrm{Gr}$ \\
\hline L. labyrinthicus & & & & & & & $\mathrm{H}$ & $\mathrm{PS}, \mathrm{Gn}, \mathrm{Gr}$ \\
\hline L. latrans & $S$ & & Ju & S & S & $S$ & $\mathrm{H}$ & Gn, Gr, PS \\
\hline L. spixi & & & & & & & $\mathrm{H}$ & Gn \\
\hline P. cuvieri & & & & & S & $S$ & $\mathrm{H}$ & Gn, PS, Gr \\
\hline R. ornata & & & & & & & $\mathrm{H}$ & Gn \\
\hline S. crospedospilus & S & & & & S & S & $\mathrm{Sh}, \mathrm{H}$ & Gn, Gr, C \\
\hline T. miliaris & S & & & & & & $\mathrm{H}$ & Gn \\
\hline $\mathbf{N}^{\circ}$ species vocalizing & 11 & 12 & 13 & 13 & 10 & 08 & & \\
\hline$N^{\circ}$ species registered & 13 & 12 & 14 & 13 & 13 & 10 & & \\
\hline
\end{tabular}
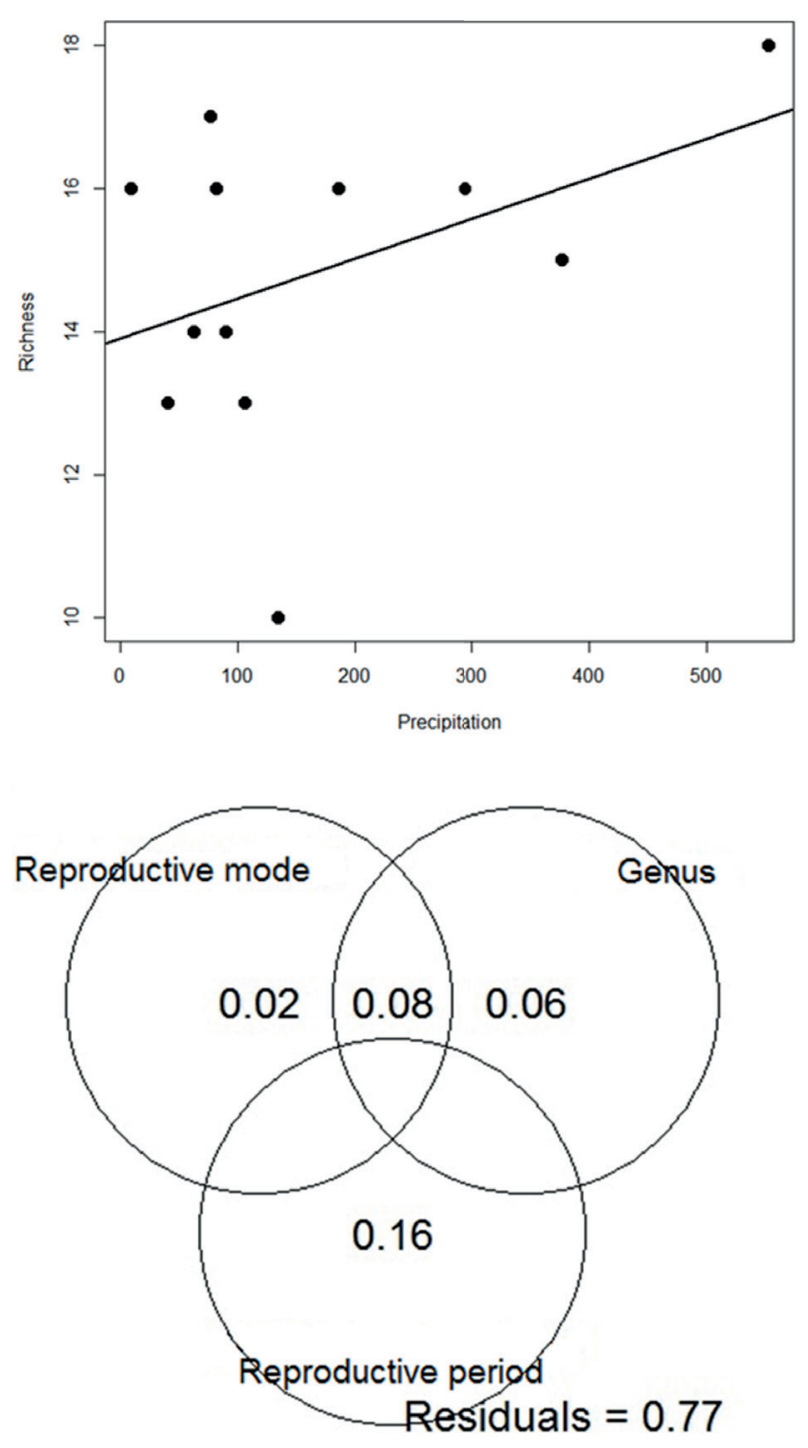

Figure 2. Linear regression comparing the richness of anurans in breeding activity with rainfall in the rainy season (October to March) between 2013-14 and 2014-15. Black dots (each point represents one month of study).
Figure 3. Venn diagram representing the percentages of each significant explanatory variable and the correlation between them based on the spatial organization of species composition in habitats in the Municipality of Barão de Monte Alto, State of Minas Gerais, Brazil. 


\section{DISCUSSION}

We found 28 species of anurans, distributed in 14 genera and 10 families: Bufonidae (1), Brachycephalidae (1), Craugastoridae (1), Cycloramphydae (1), Hylidae (14), Microhylidae (1), Leptodactylidae (6), Odontophrynidae (1), Phyllomedusidae (1) and Ranidae (1) (Table II). The assemblage of anurans studied is predominated by Hylids (sensu Pyron \& Wiens 2011), the same pattern was found in various studies in the neotropical region (e.g. Gottsberger \& Gruber 2004, Abrunhosa et al. 2006, Juncá 2006, Canelas \& Bertoluci 2007, Moreira et al. 2007, Santana et al. 2010, Pereira et al. 2016). The sampled localities do not have a strong seasonality of climatic variables (precipitation, temperature) due to the small amplitude of thermal variation during the study months. This may explain why the reproductive season of the species is not concentrated during the two rainy seasons. Some variables were more important than others and among the most important, habitat heterogeneity, reproductive period, reproductive mode, and phylogenetic distance had a greater influence on the species, as was observed in the overlap in the vocalization period of several species in the same environment. Because most of the variables are synchronized, the interactions of these external factors are often more important than a single environmental factor. The analyzed variables are discussed below.

In tropical regions rainfall seems to be the principal factor regulating the reproductive activities of anurans (Heyer 1973), because it determines the availability and duration of reproductive sites (Gottsberger \& Gruber 2004). In this study, the linear regression showed there was no relationship between the presence of actively calling species and temperature (Figure 2). The study site showed a small range of thermal variation during the study months (23 to $26.5^{\circ} \mathrm{C}$ ), which may explain why temperature had no apparent effect on the reproductive activity on anurans. However, this is not commonly found in studies of amphibian communities, which generally show correlations between reproductive activity and environmental temperature (e.g. Vasconcelos \& Rossa-Feres 2005, Conte \& Rossa-Feres 2006). Other studies have shown that the reproductive activity of only a few species within an assemblage is influenced by temperature, and also depends on their reproductive mode (Gottsberger \& Gruber 2004, Moreira et al. 2007).

Area $C$ can be considered the most heterogeneous, as it is located in a transition from pasture and secondary forest. The positive association between richness of anurans and habitat heterogeneity is compatible with various studies that relate richness of different animal groups with area and habitat heterogeneity (Ricklefs \& Lovette 1999, Vallan 2000, Báldi 2008, Silva et al. 2011, Souza et al. 2014, Araújo et al. 2018). The most accepted explanation for this association (Tews et al. 2004) is the habitat heterogeneity hypothesis (Simpson 1949). It assumes that more structurally complex environments hold more niches and have various forms of environmental resource exploitation, thus increasing species diversity (Campos \& Vaz-Silva 2010).

However, this hypothesis does not conform exactly to the results of this research, because the vertical stratification, one component of environmental heterogeneity, promoted greater hylid richness, thus allowing more species to co-exist given there was greater resource availability (Colli et al. 2002, Nogueira et al. 2009). On one hand, this explains the higher number of hylids (14) in Area A, but does not explain why Area $C$, which is also located in a forested area, does not have an equally rich 
hylid fauna. Maybe the higher richness of hylids in Area A could be best explained by the intermediate disturbance hypothesis (Connell 1978). Area $A$ is the environment that suffered the greatest and most frequent anthropogenic interference; it was used for logging Eucalyptus plantations and raising cattle. With a moderate level of disturbance, the assemblage comprises a mosaic of habitats, favoring the occurrence of high species diversity (Huston 1994, Pianka 1994, Ricklefs 2003). Changes in plant community and soil can also be instrumental in structuring the assemblage of anurans (Bastazini et al. 2007).

Temporal differences in reproductive seasons can be an important factor in the reproductive isolation of species that share the same habitat (Bertoluci \& Rodrigues 2002). We observed overlap in calling periods of many species in the same habitat (Tables IIIa, b and c). This overlap is possible because species exploit different microhabitats, which is an important factor for reproductive isolation (Cardoso et al. 1989, Pombal Junior 1997, Toledo et al. 2003), and reduces the occurrence of interspecific territorial disputes. This is the case for Boana albopunctata and B. faber, which call during the same period, but almost always occupy different microhabitats. However, Dendropsophus branneri, D. elegans, and D. minutus co-occur in all of the habitats and have overlapping calling periods. Nevertheless, Dendropsophus elegans was found calling in higher strata and sometimes in large sized trees, whereas D. branneri and D. minutus shared shrubs of aquatic vegetation. In cases of temporal and spatial overlap, reproductive isolation can occur due to acoustic divergence (Pombal Junior 1997, Bernarde \& Machado 2001, Toledo et al. 2003). Eterovick (2003) pointed out the call behavioral flexibility and interactions with physical and biotic variables as one of the determining factors of reproductive patterns in anurans.
Of the species that were not possible to establish a temporal calling pattern, such as Thoropa miliaris, it is possible that they have an explosive reproductive pattern, and their calling nights may have not coincided with our collection nights in the field (Toledo et al. 2003). This may be the case for Elachistocleis cesarii and Proceratophrys boiei, which also have explosive patterns of reproduction (Bertoluci 1998, Canelas \& Bertoluci 2007).

The phylogenetic signal related to the use of microhabitat of species reflects old evolutionary relationships, which are related to the separation between terrestrial and arboreal species during the Cretaceous period, approximately 100 million years ago (Duellman \& Trueb 1986, Igawa et al. 2008, Báez et al. 2009). Within each of these clades, other factors are related to the use of micro-habitat among the species involved, such as selective pressures of the past causing recent niche displacement or evolutionary divergence (Zimmerman \& Simberloff 1996, Eterovick et al. 2010). Although relatively small, the phylogenetic signal is fundamental in explaining the evaluated niche variation. Because, traits exhibited by species may be influenced to various degrees by their phylogenetic history, as well as contemporary selective pressures. Species in a given clade may show high similarity for traits with strong phylogenetic signal, whereas labile traits may differ even in closely related species that have diversified into different ecological niches (Richardson 2001).

In most habitats, the abiotic structure of the environment determines the community and influences the distributions and interactions of animal species (Bell et al. 1991, Tews et al. 2004). When we evaluated which variables best explain the anuran species composition among the areas, we observed that part of the explanation for reproductive mode or for genus was due 
to the correlation between the two (0.08). On the scale of this study, the reproductive modes are probably phylogenetically conserved. The presence of a phylogenetic signal indicates that phylogeny represents a fraction of the variation in the use of habitat for each species. It represents an important vertical segregation in forming patterns of diversity and local distribution of anurans. However, according to our results the factor that best explained the differences in individual habitats was the reproductive period (0.16) (Figure 3). Because the species may differ in their annual reproductive periods (Wells 1977), daily periods of calling activity, acoustic parameters of their advertisement calls, and time sharing of resources are important mechanisms of reproductive isolation (Wells 1977). A phylogenetically pooled community contains species that are, on average, more related than expected by chance (Webb 2000, Webb et al. 2002). The results of this study demonstrate that the occupation of breeding sites does not occur randomly, but occurs through the selection of preferred habitats for individual species. The habitat level can be related to phylogenetic niche conservation, which is maintained during the process of Atlantic Forest occupation by the group studied.

\section{Acknowledgments}

We would like to thank everyone who helped us during the fieldwork. All residents of Barão de Monte Alto. EAP thanks Coordenação de Aperfeiçoamento de Pessoal de Nivel Superior (CAPES) for financial support and the Instituto Chico Mendes de Conservação da Biodiversidade - ICMBio for collecting license.

\section{REFERENCES}

ABRUNHOSA PA, WOGEL H \& POMBAL JUNIOR JP. 2006. Anuran temporal occupancy in a temporary pond from the Atlantic Rain Forest, South-Eastern Brazil. Herpetol J 16: $115-122$.
AICHINGER M. 1987. Annual activity patterns of anurans in a seasonal Neotropical environment. Oecologia 71: 583-592.

ARAÚJO KC, GUZZI A \& ÁVILA RW. 2018. Influence of habitat heterogeneity on anuran diversity in Restinga landscapes of the Parnaíba River delta, Northeastern Brazil. ZooKeys 757: 69.

ARZABE C. 1999. Reproductive activity patterns of anurans in two different altitudinal sites within the Brazilian Caatinga. Rev Bras Zool 16: 851-864.

BÁEZ AM, MOURA GJB \& GOMEZ RO. 2009. Anurans from the Lower Cretaceous Crato Formation of Northeastern Brazil: implications for the early divergence of neobatrachians. Cretac Res 30: 829-846.

BÁLDI A. 2008. Habitat heterogeneity overrides the species-area relationship. J Biogeogr 35: 675-681.

BARBAULT R. 1991. Ecological constraints and community dynamics linking community patterns to organismal ecology. The case of herpetofaunas. Acta Oecol 12: 139-163.

BASTAZINI CM, MUNDURUCA JFV, ROCHA PLB \& NAPOLI MF. 2007. Which environmental variables better explain changes in anuran community composition? A case study in the restinga of Mata de São João, Bahia, Brazil. Herpetologica 63: 459-471.

BASTOS RP. 2007. Anfíbios do Cerrado. In Herpetologia no Brasil II. In: Nascimento LB and Oliveira ME (Eds), Sociedade Brasileira de Herpetologia. Belo Horizonte, p. $87-100$.

BEGON M, HARPER JL \& TOWNSEND CR. 1990. Ecology. Individuals, populations and communities. Blackwell scientific publications. Blackwell Scientific Publications, Oxford, p. 611-615.

BELL SS, MCCOY ED \& MUSHINSKY HR. 1991. Habitat structure the physical arrangement of objects in space. London: chapman and Hall.

BERNARDE PS \& ANJOS L. 1999. Distribuição espacial e temporal da anurofauna do Parque Estadual Mata dos Godoy, Londrina, Paraná, Brasil (Amphibia, Anura). Comunicações do Museu Ciências e Tecnologia da PUCRS. Série Zoologia 2: 127-140.7.

BERNARDE PS \& KOKUBUM MNC. 1999. Anurofauna do Município de Guararapes, Estado de São Paulo, Brasil (Amphibia: Anura). Acta Biol Leopoldinense 21: 89-97.

BERNARDE PS \& MACHADO RA. 2001. Riqueza de espécies, ambientes de reprodução e temporada de vocalização 
da anurofauna em Três Barras do Paraná, Brasil (Amphibia: Anura). Cuad Herpetol 14: 93-194.

BERTOLUCI J. 1998. Annual patterns of breeding activity in Atlantic Rainforest anurans. J Herpetol 32: 607-611.

BERTOLUCI J \& RODRIGUES MT. 2002. Utilização de habitats reprodutivos e micro-habitats de vocalização em uma taxocenose de anuros (Amphibia) da Mata Atlântica do sudeste do Brasil. Pap Avulsos Zool 42: 287-297.

BORCARD D, LEGENDRE P \& DRAPEAU P. 1992. Partialling out the spatial component of ecological variation. Ecology 73: 1045-1055.

BRANDÃO RA \& ARAÚJO AFB. 1998. A herpetofauna da Estação Ecológica de Águas Emendadas. Vertebrados da Estação Ecológica de Águas Emendadas. História Natural e Ecologia em um fragmento de cerrado do Brasil Central. In: Marinho-Filho J, Rodrigues F and Guimarães M (Eds), SEMATEC/IEMA, Brasília, p. 9-21.

CAMPOS FS \& VAZ-SILVA W. 2010. Distribuição espacial e temporal da anurofauna em diferentes ambientes no Município de Hidrolândia, GO, Brasil Central. Neotrop Biol Conserv 5: 179-187.

CANELAS MAS \& BERTOLUCI J. 2007. Anurans of the Serra do Caraça, Southeastern Brazil: species composition and phenological patterns of calling activity. Iheringia-Sér Zool 97: 21-26.

CARDOSO AJ, ANDRADE GV \& HADDAD CFB. 1989. Distribuição espacial em comunidades de anfíbios (Anura) no SE do Brasil. Rev Bras Biol 49: 241-249.

CARDOSO AJ \& HADDAD CFB. 1992. Diversidade e turno de vocalizações de anuros em comunidade neotropical. Acta Zool Lilloana 41: 93-105.

CLOYED CS \& EASON PK. 2017. Niche partitioning and the role of intraspecific niche variation in structuring a guild of generalist anurans. R Soc Open Sci 4: 170060. doi: $10.1098 /$ rsos.170060.

COLLI GR, BASTOS RP \& ARAÚJO AFB. 2002. The character and dynamics of the Cerrado herpetofauna. The Cerrados of 32 Brazil: Ecology and Natural History of a Neotropical Savanna. In: Oliveira PS and Marquis RJ (Eds), Columbia University Press, New York, p. 223-241.

CONNELL JH. 1978. Diversity of tropical rainforests and coral reefs. Science 199: 1304-1310.

CONTE CE \& MACHADO RA. 2005. Riqueza de espécies e distribuição espacial e temporal em comunidade de anfíbios anuros (Amphibia, Anura) em uma localidade do Município de Tijucas do Sul, Paraná, Brasil. Rev Bras Zool 22: 940-948.
CONTE CE \& ROSSA-FERES DC. 2006. Diversidade e ocorrência temporal da anurofauna (Amphibia, Anura) em São José dos Pinhais, Paraná, sul do Brasil. Rev Bras Zool 23 : 162-175.

COSTA GC, FRANÇA KL, OLIVEIRA-JÚNIOR TM \& PICHORIM MAURO. 2016. Uso e coexistência de habitat em duas espécies intimamente relacionadas de Herpsilochmus (Aves: Thamnophilidae). Cogent Environ Sci 2: 1. doi: 10.1080 / 23311843.2016.1264126

CRUMP ML. 1974. Reproductive strategies in a tropical anuran community. Miscellaneous Publication of the Museum of Natural History of University of Kansas 61: $1-68$.

DÍAZ-PANIAGUA C. 1990. Temporary ponds as breeding sites of amphibians at a locality in Southwestern Spain. Herpetol J 1: 447-453.

DUELLMAN WE \& TRUEB L. 1986. Biology of Amphibians. New York: McGraw-Hill, $670 \mathrm{p}$.

ETEROVICK PC. 2003. Distribution of anuran species among montane streams in South-Eastern Brazil. J Trop Ecol 19: 219-228.

ETEROVICK PC \& FERNANDES GW. 2001. Tadpole distribution within montane meadow streams at the Serra do Cipó, southeastern Brazil: ecological or phylogenetic constraints? J Trop Ecol 17: 683-693.

ETEROVICK PC, RIEVERS CR, WACHLEVSKI M, FRANCO BP \& AFONSO LG. 2010. Lack of phylogenetic signal in the variation in anuran microhabitat use in Southeastern Brazil. Evol Ecol 24: 1-24.

ETEROVICK PC \& SAZIMA I. 2000. Structure of an anuran community in a montane meadow in southeastern Brazil: effects of seasonality, habitat, and predation. AmphibiaReptilia 21: 439-461.

ETEROVICK PC \& SAZIMA I. 2004. Anfíbios da Serra do Cipó, Minas Gerais, Brasil. Editora PUCMINAS, Belo Horizonte.

GOTTSBERGER B \& GRUBER E. 2004. Temporal partitioning of reproductive activity in a Neotropical anuran community. J Trop Ecol 20: 271-280.

HADDAD CF \& PRADO CP. 2005. Reproductive modes in frogs and their unexpected diversity in the Atlantic Forest of Brazil. Bioscience 55: 207-217.

HADDAD CFB \& SAZIMA I. 1992. Anfíbios anuros da Serra do Japi. In: História natural da Serra do Japi: ecologia e preservação de uma área florestal no sudeste do Brasil. Morellato LPC (Org), Unicamp, Campinas, São Paulo, Brazil, p. 118-211. 
HADDAD CFB, TOLEDO LF, PRADO CPA, LOEBMANN D, GASPARINI JL \& SAZIMA I. 2013. Guia dos anfíbios da Mata Atlântica diversidade e biologia. Anolis Books, São Paulo, 542 p.

HARTEL T, BANCILA R \& COGALNICEANU D. 2011. Spatial and temporal variability of aquatic habitat use by amphibians in a hydrologically modified landscape. Freshw Biol 56: 2288-2298.

HEYER WR. 1973. Ecological interactions of frog larvae at a seasonal tropical location in Thailand. J Herpetol 7: 337-361.

HEYER WR, DONNELLY MA, MCDIARMID RW, HAYEK LC \& FOSTER MS. 1994. Measuring and monitoring biological diversity. Standard methods for Amphibians. Smithsonian Institution Press, Washington.

HUSTON MA. 1994. Biological diversity - the coexistence of species on changing landscapes. Cambridge University Press, New York.

IGAWA T, KURABAYASHI A, USUKI C, FUJII T \& SUMIDA M. 2008. Complete mitochondrial genomes of three Neobatrachian anurans: a case study of divergence time estimation using different data and calibration settings. Gene 407: 116-129.

JUNCÁ FA. 2006. Diversidade e uso de hábitat por anfíbios anuros em duas localidades de Mata Atlântica, no norte do estado da Bahia. Biota Neotrop 6: 1-17.

KOPP K, SIGNORELLI L \& BASTOS RP. 2010. Temporal distribution and diversity of reproductive modes in anuran amphibians in the Emas National Park and surrounding area, State of Goiás, Brazil. Iheringia Ser Zool 100: 192-200.

KÖPPEN WP. 1918. Klassification der Klimate nach Temperatur, Niederschlag und Jahreslauf. Petermanns Mitteilungen 64: 193-203.

KOTTEK M, GRIESER J, BECK C, RUDOLF B \& RUBEL F. 2006. World Map of the Köppen-Geiger climate classification updated. Meteorol Z 15: 259-263.

LILLYWHITE H, LICHT P \& CHELGREN P. 1973. Role of behavioral thermoregulation in growth energetics of toad, Bufo boreas. Ecology 54: 375-383.

LOSOS JB. 1996. Phylogenetic perspectives on community ecology. Ecology 77: 1344-1354.

MACARTHUR RH \& MACARTHUR JW. 1961. On bird species diversity. Ecology 42: 594-598.

MACARTHUR RH \& WILSON EO. 1967. The theory of island biogeography. Princeton University Press, New Jersey.
MAECHLER M, ROUSSEEUW P, STRUYF A, HUBERT M \& HORNIK K. 2015. Cluster: cluster analysis basics and extensions. $R$ package. Available from: https://cran.r-project.org/web/ packages/cluster/index.html.

MAFFEI F, UBAID FK \& JIM J. 2011. Anurans in an open Cerrado area in the Municipality of Borebi, São Paulo state, Southeastern Brazil: habitat use, abundance and seasonal variation. Biota Neotrop 11: 221-233.

MANLY BFG. 1994. A Primer of Multivariate Statistics. Chapman and Hall, London.

MENIN M, ROSSA-FERES DDC \& GIARETTA AA. 2005. Resource use and coexistence of two syntopic hylid frogs (Anura, Hylidae). Rev Bras Zool 22: 61-72.

MOREIRA LFB, MACHADO IF, LACE ARGM \& MALTCHIK LG. 2007. Calling period and reproductive modes in an anuran community of a temporary pond in Southern Brazil. S Am J Herpetol 2: 129-135.

NECKEL-OLIVEIRA S, MAGNUSSON WE, LIMA AP \& ALBERNAZ ALK. 2000. Diversity and distribution of frogs in an Amazonian savanna in Brazil. Amphibia-Reptilia 21: 317-326.

NOGUEIRA C, COLLI GR \& MARTINS M. 2009. Local richnesS and distribution of the lizard fauna in natural habitat mosaics of the Brazilian Cerrado. Austral Ecol 34: 83-96.

OKSANEN JF, BLANCHET G, KINDT R, LEGENDRE P, MINCHIN PR, O'HARA RB \& WAGNER H. 2015. Vegan: community ecology, R package. Available from: http://CRAN.R-project.org/ package=vegan .

PARADIS E, CLAUDE J \& STRIMMER K. 2004. APE: analyses of phylogenetics and evolution in $\mathrm{R}$ language. Bioinformatics 20: 289-290.

PEREIRA EA, NEVES MO, HOTE PS, SANTANA DJ \& FEIO RN. 2016. Anurans of the Municipality of Barão de Monte Alto, Minas Gerais, Brazil. Check List 12: 1-13.

PIANKA ER. 1969. Sympatry of desert lizards (Ctenotus) in Western Australia. Ecology 50: 1012-1030.

PIANKA ER. 1994. Evol Ecol Harper Collins College Publishers, New York.

POMBAL JUNIOR JP. 1997. Distribuição espacial e temporal de anuros (Amphibia) em uma poça permanente na Serra de Paranapiacaba, Sudeste do Brasil. Rev Bras Biol 57: 583-594.

PRADO CPA, UETANABARO M \& HADDAD CFB. 2005. Breeding activity patterns, reproductive modes, and habitat use by anurans (Amphibia) in a seasonal environment in the Pantanal, Brazil. Amphibia-Reptilia 26: 211-221. 
PULLIAM PN. 1989. Individual behaviour and the procurement of essential resources. Perspectives in Ecological Theory. In: Roughgarden J, May RM and Levin AS (Eds), Princeton University Press, Princeton, p. 25-38.

PURRENHAGE JL \& BOONE MD. 2009. Amphibian community response to variation in habitat structure and competitor density. Herpetologica 65: 14-30.

PYRON RA \& WIENS JJ. 2011. A large-scale phylogeny of Amphibia including over 2800 species, and a revised classification of extant frogs, salamanders, and caecilians. Mol Phylogenet Evol 61: 543-583.

R CORE TEAM. 2015. R: A language and environment for statistical computing. R Foundation for Statistical Computing, Vienna, Austria. Available from: http:// www.R-project.org/.

RICHARDSON JML. 2001. The relative roles of adaptation and phylogeny in determination of larval traits indiversifying anuran lineages. Am Nat 157: 282-299.

RICHTER-BOIX A, LLORENTE GA \& MONTORI A. 2006. A comparative analysis of the adaptive developmental hypothesis in six Mediterranean anuran species along a pond permanency gradient. Evol Ecol Res 8: 1139-1154.

RICKLEFS RE. 2003. A economia da natureza. $5^{\text {th }}$ Edition. Guanabara Koogan, Rio de Janeiro.

RICKLEFS RE \& LOVETTE IJ. 1999. The roles of island area per se and habitat diversity in the species -area relationships of four Lesser Antillean faunal groups. J Anim Ecol 68: 1142-1160.

ROJAS-AHUMADA DP, LANDEIRO VL \& MENIN M. 2012. Role of environmental and spatial processes in structuring anuran communities across a tropical rain forest. Austral Ecol 37: 865-873.

ROSSA-FERES DC \& JIM J. 2001. Similaridade no sítio de vocalização em uma comunidade de anfíbios anuros na região noroeste do Estado de São Paulo, Brasil. Rev Bras Zoo 18: 439-454.

SABBAG AF \& ZINA J. 2011. Anurans of a riparian forest in Sao Carlos, State of São Paulo, Brazil. Biota Neotrop 11: 179-188.

SANTANA DJ, SÃO PEDRO VA, HOTE PS, ROBERTI HM, SANTA'ANNA AC, FIGUEIREDO-DE-ANDRADE CA \& FEIO RN. 2010. Anurans in the Region of the High Muriaé River, State of Minas Gerais, Brazil. Herpetol. Notes 3: 1-10.

SANTOS TG, KOPP K, SPIES MR, TREVISAN R \& CECHIN SZ. 2008. Temporal and spatial distribution of anurans in the Pampa Region (Santa Maria, RS). Iheringia Ser Zool 98: 244-253.
SANTOS TG, VASCONCELOS TS, ROSSA-FERES DC \& HADDAD CFB. 2009. Anurans of a seasonally dry tropical forest: Morro do Diabo State Park, São Paulo state, Brazil. J Nat Hist 43: 973-993.

SCHINEIDER JAP \& TEIXEIRA RL. 2001. Relacionamento entre anfíbios anuros e bromélias da Restinga de Regência, Linhares, Espírito Santo, Brasil. Iheringia 62: 263-268.

SCHIRMER A, HERDE A, ECCARD JA \& DAMMHAHN M. 2019. Individuals in space: personality-dependent space use, movement and microhabitat use facilitate individual spatial niche specialization. Oecologia: 1-14.

SHIROSE LJ, BISHOP CA, GREEN DM, MACDONALD CJ, BROOKS RJ \& HELFERTY NJ. 1997. Validation tests of an amphibian call count survey technique in Ontario, Canada. Herpetologica 53: 312-320.

SILVA RA, MARTINS IA \& ROSSA-FERES DDC. 2011. Environmental heterogeneity: Anuran diversity in homogeneous environments. Zoologia 28.

SIMPSON EH. 1949. Measurement of diversity. Nature 163: 688.

SKELLY DK, WERNER EE \& CORTWRIGHT SA. 1999. Long-term distributional dynamics of a Michigan amphibian assemblage. Ecology 80: 2326-2337.

SOUZA FL, MARTINS FI \& RAIZER J. 2014. Habitat heterogeneity and anuran community of an agroecosystem in the Pantanal of Brazil. Phyllomedusa: J Herpetol 13: 41-50.

TEWS J, BROSE U, GRIMM V, TIELBORGER K, WICHMANN MC, SCHWAGER M \& JELTSCH F. 2004. Animal species diversity driven by habitat heterogeneity/diversity: the importance of keystone structures. J Biogeogr 31: 79-92.

TOFT CA. 1985. Resource partitioning in amphibians and reptiles. Copeia 1985: 1-21.

TOLEDO LF, ZINA J \& HADDAD CFB. 2003. Distribuição espacial e temporal de uma comunidade de anfíbios anuros do Município de Rio Claro, São Paulo, Brasil. Holos Environment 3: 136-149.

VALLAN D. 2000. Influence of forest fragmentation on amphibian diversity in the nature reserve of Ambohitantely, highland Madagascar. Biol Conserv 96: 31-43.

VAN BEEST FM, MCLOUGHLIN PD, VANDER WAL E \& BROOK RK. 2014. Density-dependent habitat selection and partitioning between two sympatric ungulates. Oecologia 175: 1155-1165.

VASCONCELOS TS \& ROSSA-FERES DC. 2005. Diversidade, distribuição espacial e temporal de anfíbios anuros 
(Amphibia, Anura) na região noroeste do Estado de São Paulo, Brasil. Biota Neotrop 5: 1-14.

VELOSO HP, RANGEL FILHO ALR \& LIMA JCA. 1991. Classificação da vegetação brasileira adaptada a um sistema universal. IBGE: Departamento de Recursos Naturais e Estudos Ambientais, Rio de Janeiro.

VOGEL HF, ZAWADZKI H \& METRI R. 2011. Coexistência entre Turdus leucomelas Vieillot, 1818 e Turdus rufiventris Vieillot, 1818 (Aves: Passeriformes) em um fragmento urbano de floresta com araucárias, Sul do Brasil. Biota Neotrop 11.

WEBB CO. 2000. Exploring the phylogenetic structure of ecological communities: An example for rain forest trees. Am Nat 156: 145-155.

WEBB CO, ACKERLY DD, MCPEEK MA \& DONOGHUE MJ. 2002. Phylogenies and community ecology. Annu Rev Eco Evo Syst 33: 475-505.

WELLS KD. 1977. The courtship of frogs. The reproductive biology of amphibians. In: Taylor DH and Guttman SI (Eds), Plenum, New York, 475 p.

WELLS KD. 2007. The Ecology and Behavior of Amphibians. The University of Chicago Press, Chicago.

ZIMMERMAN BL \& SIMBERLOFF D. 1996. An historical interpretation of habitat uses by frogs in a Central Amazonian Forest. J Biogeogr 23: 27-46.

\section{How to cite}

PEREIRA EA, NEVES MO, SUGAI JLMM, FEIO RN \& SANTANA DJ. 2020. Seasonal and habitat structure of an anuran assemblage. An Acad Bras Cienc 92: e20190458. DOI 10.1590/0001-3765202020190458.

Manuscript received on May 10, 2019;

accepted for publication on August 15, 2019

ELVIS A. PEREIRA ${ }^{1,2,3}$

https://orcid.org/0000-0002-8810-7878

MATHEUS O. NEVES ${ }^{2,4}$

https://orcid.org/0000-0002-6848-2099

JOSÉ LUIZ M.M. SUGAI

https://orcid.org/0000-0003-1480-4053

RENATO N. FEIO 6

https://orcid.org/0000-0002-3607-2896

DIEGO J. SANTANA ${ }^{2,5}$

http://orcid.org/0000-0002-8789-3061
'Programa de Pós-Graduação em Biologia Animal, Universidade Federal Rural do Rio de Janeiro, Rodovia BR 465, Km 7, 23890-000 Seropédica, RJ, Brazil

${ }^{2}$ Mapinguari - Laboratório de Biogeografia e Sistemática de Anfíbios e Répteis, Universidade Federal de Mato Grosso do Sul, Cidade Universitária, Avenida Costa e Silva, s/n, Pioneiros, 79002-900 Campo Grande, MS, Brazil

${ }^{3}$ Technische Universität Braunschweig, Zoological Institute, Mendelssohnstrasse 4, 38106, Braunschweig, Germany

${ }^{4}$ Programa de Pós-Graduação em Ecologia e Conservação, Universidade Federal de Mato Grosso do Sul, Centro de Ciências Biológicas e da Saúde, Cidade Universitária, Avenida Costa e Silva, s/n, Pioneiros, 79070-900 Campo Grande, MS, Brazil

${ }^{5}$ Universidade Federal de Mato Grosso do Sul, Laboratório de Zoologia, Centro de Ciências Biológicas e da Saúde, Cidade Universitária, Avenida Costa e Silva, s/n, Pioneiros, 79070-900 Campo Grande, MS, Brazil

${ }^{6}$ Universidade Federal de Viçosa, Museu de Zoologia João Moojen, Departamento de Biologia Animal, Avenida Peter Henry Rolfs, s/n, Campus Universitário, 36570-900 Viçosa, Minas Gerais, Brazil

Correspondence to: Elvis Almeida Pereira

E-mail:elvisaps@hotmail.com

\section{Authors Contributions}

Elvis Almeida Pereira conceived and designed the experiments, performed the experiments, analyzed the data, prepared figures and/or tables, authored or reviewed drafts of the paper, approved the final draft. Matheus de Oliveira Neves performed the experiments, authored or reviewed drafts of the paper, approved the final draft. José Luíz Massao Moreira Sugai analyzed the data and approved the final draft. Diego José Santana conceived and designed the experiments, performed the experiments, analyzed the data, contributed analysis tools, authored or reviewed drafts of the paper, approved the final draft. Renato Neves Feio authored or reviewed drafts of the paper, approved the final draft.

\section{(cc) BY}

